\title{
EVALUATION OF SURROGATE MARKERS FOR HUMAN IMMUNODEFICIENCY VIRUS INFECTION AMONG BLOOD DONORS AT THE BLOOD BANK OF "HOSPITAL UNIVERSITÁRIO REGIONAL NORTE DO PARANÁ", LONDRINA, PR, BRAZIL
}

\author{
Edna Maria Vissoci REICHE(1), Ingridt Hildegard VOGLER(1), Helena Kaminami MORIMOTO(1), André Luis BORTOLIERO(2,3), Tiemi MATSUO(4),
} Kátia Kioko YUAHASI(5), Sanderson Júnior CANCIAN(5) \& Roberto Setsuo KOGUICHI(5).

\begin{abstract}
SUMMARY
This study evaluated the usefulness of the anti-HBc, hepatitis $\mathrm{C}$ virus antibodies (anti-HCV), human T cell lymphotropic virus I and II antibodies (anti-HTLV I/II), serologic tests for syphilis, and surface antigen of hepatitis B virus (HBsAg) as surrogate markers for the risk for HIV infection in 80,284 serum samples from blood donors from the Blood Bank of "Hospital Universitário Regional Norte do Paraná", Londrina, Paraná State, Brazil, analyzed from July 1994 to April 2001. Among 39 blood donors with positive serology for HIV, 12 (30.8\%) were anti-HBc positive, 10 (25.6\%) for anti-HCV, 1 (2.6\%) for anti-HTLV I/I, 1 (2.6\%) was positive for syphilis, and 1 (2.6\%) for HBsAg. Among the donors with negative serology for HIV, these markers were detected in 8,407 (10.5\%), $441(0.5 \%), 189(0.2 \%), 464(0.6 \%)$, and $473(0.6 \%)$ samples, respectively. The difference was statistically significant $(\mathrm{p}<0.001)$ for anti-HBc and anti-HCV. Although the predictive positive value for these surrogate markers were low for HIV infection, the results confirmed the anti-HBc and anti-HCV as useful surrogate markers for HIV infection thus reinforcing the maintenance of them in the screening for blood donors contributing to the prevention of the small number of cases in which HIV is still transmitted by transfusion.
\end{abstract}

KEYWORDS: Surrogate markers; Human immunodeficiency virus infection (HIV); Blood donors; Serological screening; Anti$\mathrm{HBc}$; Anti-HCV .

\section{INTRODUCTION}

In industrialized countries, the use of sensitive human immunodeficiency virus (HIV) screening tests, donor deferral, and more conservative use of blood have resulted in a dramatic decrease in the transmission of HIV infection by blood transfusion. The risk of HIV transmission in the United States by blood screened negative for HIV antibody was recently estimated at one in 440,000-660,000 donations. However, in many developing countries where the prevalence of HIV infection among blood donors is orders of magnitude greater than in industrialized countries, an estimated 5 to $10 \%$ of HIV infections are due to blood transfusion ${ }^{10}$. More strategies and measures to improve the effectiveness of the routine screening of blood donors and the safety of the blood components have been evaluated.

The rate of hepatitis B virus (HBV) infection in HIV infected patients is 10-30 times higher then in general population from United States ${ }^{19}$. During the $\mathrm{HBV}$ infection, the $\mathrm{HBV}$ produces envelope protein or surface antigen (HBsAg) in vast excess during the period before seroconversion. For this reason, antigen tests with sufficient sensitivity were available for blood donation screening at a very early stage. With exposure to the neutralizing anti-HBs antibodies, the HBsAg disappears. The core particle of the hepatitis $\mathrm{B}$ virus $(\mathrm{HBcAg})$ is an extremely potent antigen that elicits strong B- and T-cell responses in individuals exposed to the virus. The antibody to core antigen (anti-HBc) occurs early in acute infection, 4-10 weeks after appearance of surface antigen of hepatitis B virus (HBsAg), usually persists longer, or for lifetime, than other hepatitis B virus (HBV) markers, is associated with an elevated risk of transmission of non-A non-B hepatitis and has been used as a surrogate to screen blood donors ${ }^{14,20}$. Anti-HBc was introduced in routine donor screening in 1987 in an attempt to identify donors at risk of transmitting posttransfusion non-A non-B hepatitis ${ }^{13}$. Anti-HBc detects persons who have been previously infected with $\mathrm{HBV}$ and can therefore serve as surrogate test for other infectious agents. In addition to indicating previous exposure to $\mathrm{HBV}$, the anti-HBc assays have been used as surrogate marker for the presence of other infectious agents. In some blood banks in regions of high prevalence of HIV infection, the anti-HBc was implemented as a surrogate test for HIV infection ${ }^{9}$. Exclusion of anti-HBc positive donors reduces the incidence of post-transfusion hepatitis and possibly other virus infection, such as HIV infection, due the frequency of dual infection. 


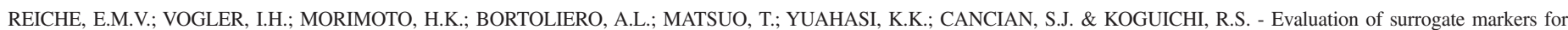
human immunodeficiency virus infection among blood donors at the blood bank of "Hospital Universitário Regional Norte do Paraná", Londrina, PR, Brazil. Rev. Inst. Med. trop. S. Paulo, 45(1):23-27, 2003.

The rate of anti-HBc among blood donors in the United Sates ranged from $1.0 \%{ }^{6}$ to $1.5 \%$. The anti-HBc is present without other serologic markers and with normal alanine aminotransferase (ALT) in $2 \%$ of routine blood donors in the United States; $70 \%$ of these are due to recovery from subclinical HBV infection, and may be infectious, and the rest are considered false-positive ${ }^{19}$. In Brazil, anti-HBc ant ALT were introduced in blood donor screening in November $1993^{14}$. The prevalence of anti$\mathrm{HBc}$ among blood donors in Brazil ranged from $5.40 \%$ to $18.18 \%$, according to different regions of the country ${ }^{14}$.

The discovery of hepatitis C virus (HCV) in $1989^{3}$ and the subsequent introduction of specific screening tests for anti- $\mathrm{HCV}$ have reduced the rate of $90 \%$ of post-transfusion hepatitis infection. The anti-HCV antibodies are detected from 12 to 20 weeks after the onset of clinical signs and symptoms. During this phase, antibodies have not yet a chance to develop, but infectious virus is already prevalent in blood ${ }^{14}$. After the discovery of the $\mathrm{HCV}$, the agent of $90 \%$ of transfusional non-A non-B hepatitis, the maintenance of anti-HBc and ALT was questioned. In 1995, the National Institute of Health $(\mathrm{NIH})$ of the United States recommended the maintenance of the anti-HBc test because of its potential to prevent some cases of post-transfusional HBV hepatitis, it acts as a surrogate marker for HIV infection in blood donors and could decrease the residual risk of the HIV infection transmitted by blood transfusion ${ }^{1,14}$. In the absence of consistent studies that would permit the exclusion of the anti$\mathrm{HBc}$ and ALT tests, many countries such as the United States, France, and Brazil have maintained these tests in the serologic screening of blood donors ${ }^{14}$.

In 1972, American institutions recommended eliminating serologic test for syphilis (STS) screening of blood donors because of its limited public health value, but the recommendation was not implemented. In 1983, the STS was reevaluated, and the Food and Drug Administration (FDA) decided to retain it because of its potential value as a marker of behavior placing subjects at risk for HIV infection. However, no large study has established that the STS is a valuable marker of HIV infection among blood donors ${ }^{6}$.

The human T cell lymphotropic virus I and II (HTLV I/II) can be transmitted by blood and cellular blood products, maternal milk, sexual contact and by the shared use of syringes and needles among intravenous drugs abusers ${ }^{18}$. Rates of prevalence of anti-HTLV I/II among patients with acquired immunodeficiency syndrome, homosexual men, HIV infected patients and intravenous drug users are registered ${ }^{4,18}$. In this study, we evaluated the importance of surrogate markers such as anti$\mathrm{HBc}$, anti-HCV, anti-HTLV I/II antibodies, serologic test for syphilis (STS), and HBsAg for the risk for HIV infection among blood donors.

\section{MATERIAL AND METHODS}

Serum samples: This study was a retrospective evaluation of the serologic results of anti-HIV, anti-HBc, anti-HCV and anti-HTLV I/II antibodies, STS, and the presence of HBsAg obtained in 80,284 serum samples from blood donors of the Blood Bank of "Hospital Universitário Regional Norte do Paraná", Londrina, southern region of Brazil, assayed from July 1994 to April 2001.

Routine laboratory procedures: All the donations were tested for infectious diseases as required by the national advisory recommendations.
The tests performed were for anti-HBc by enzyme linked immunosorbent assay (ELISA, Abbott Laboratories and Organon Teknika), anti-HCV and HBsAg by microparticle enzyme linked immunosorbent assay thirdgeneration (MEIA, Abbott Laboratories), anti-HTLV I/II was assayed by ELISA (Embrabio, São Paulo), screening tests for anti-HIV types 1 and 2 (viral lysate and recombinant antigens) by ELISA (Abbott Laboratories, Organon Teknika, Behring Institute, Sanofi Pasteur) and confirmatory tests (indirect immunofluorescence and/or Western Blot) supported by Laboratório Central (LACEN, Curitiba, PR, Brazil). The STS used was the Venereal Disease Research Laboratories test (VDRL, Laborclin, Pinhais, PR, Brazil).

Statistical Analysis: It was assessed the prevalence, sensitivity, positive predictive value (PPV), and relative prevalence (RP) of the surrogate markers assayed, with $95 \%$ confidence interval (CI). For the analyses of the results, the Fisher Exact Test $(\mathrm{p}<0.001)$ was used.

\section{RESULTS}

The overall prevalence of the serologic markers assayed is shown in Table 1 . Thirty-nine donations $(0.05 \%)$ were anti-HIV reactive, 8,419 (10.50\%) anti-HBc reactive, $451(0.56 \%)$ anti-HCV positive, $190(0.24 \%)$ anti-HTLV I/II positive, $465(0.58 \%)$ STS reactive, and $474(0.59 \%)$ $\mathrm{HBs}$ Ag reactive.

\section{Table 1}

Overall prevalence of the anti-HIV, anti-HBc, anti-HCV, anti-HTLV I/II serologic markers, serologic tests for syphilis (STS), and HBsAg in 80,284 serum samples from blood donors of the Blood Bank of "Hospital Universitário

Regional Norte do Paraná", Londrina, from July 1994 to April 2001

\begin{tabular}{lcc}
\hline Serologic Marker & $\begin{array}{c}\text { Number of } \\
\text { Reactive } \\
\text { Serum samples }\end{array}$ & $\begin{array}{c}\% \text { Reactivity } \\
(\%)\end{array}$ \\
\hline Anti-HIV & 39 & 0.05 \\
Anti-HBc & 8,419 & 10.50 \\
Anti-HCV & 451 & 0.56 \\
Anti-HTLV I/II & 190 & 0.24 \\
Serologic test for syphilis (STS) & 465 & 0.58 \\
HBsAg & 474 & 0.59 \\
\hline
\end{tabular}

Anti-HIV: human immunodeficiency virus antibody; Anti-HBc: antibody to hepatitis B virus core antigen; Anti-HCV: hepatitis C virus antibody; Anti-HTLV I/II: human T-lymphotropic virus I and II antibodies; HBsAg: hepatitis B virus surface antigen

The results of the relationship between the anti-HIV results and the serologic surrogate markers of anti-HBc, anti-HCV, anti-HTLV I/II, STS, and the presence of HBsAg showed that among 39 blood donors with positive serology for anti-HIV, $12(30.80 \%)$ were anti-HBc positive, 10 (25.60\%) anti-HCV positive, 1 (2.60\%) anti-HTLV I/I positive, 1 (2.60\%) STS positive, and $1(2.60 \%)$ HBsAg positive. Among the blood donors with negative serology for anti-HIV, these markers were detected in 8,407 (10.50\%), $441(0.50 \%), 189(0.20 \%), 464(0.60 \%)$, and $473(0.60 \%)$ of samples, respectively. The difference was statistically significant $(\mathrm{p}<$ 0.001 ) for anti-HBc and anti-HCV, as determined by the Fisher Exact Test (Table 2). 


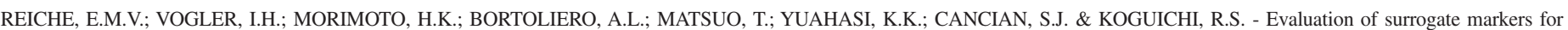

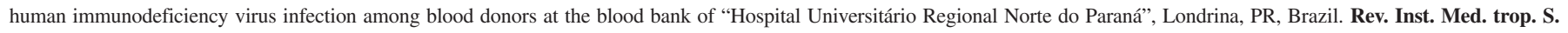
Paulo, 45(1):23-27, 2003.

The sensitivity, PPV and RP of the surrogate markers assayed for anti-HIV results are summarized in Table 3.

\section{DISCUSSION}

The anti-HBc reactivity obtained in this study (10.50\%) was higher when compared to that reported in blood donor screening surveys in the United States $^{6,9,19}$, and to the seroprevalence of Brazil (average 8.65\%), but was lower than the rate of $14.06 \%$ registered among donors from the southern region of Brazil ${ }^{14}$. The other overall prevalence rates of the serologic surrogate markers for anti-HIV, anti-HTLV I/II, HBsAg, and STS were higher when compared with the rates of five blood centers within the United States and previous reported ${ }^{6,9}$. The rates of anti-HCV and HBsAg were lower when compared with the rates registered among Brazilian blood donors $(1.22 \% \text { and } 0.97 \% \text {, respectively })^{14}$. Among the 39 anti-HIV seropositive donations, 12 (30.80\%) were anti-HBc reactive, which means that the sensitivity of anti-HBc in detecting an anti-HIV

Table 2

Prevalence of the surrogate markers anti-HBc, anti-HCV, anti-HTLV I/II, serologic test for syphilis (STS) and HBsAg in anti-HIV reactive and antiHIV nonreactive serum samples from blood donors of the Blood Bank of "Hospital Universitário Regional Norte do Paraná", Londrina, Brazil, from July 1994 to April 2001

\begin{tabular}{lrrrrr}
\hline \multirow{2}{*}{ Surrogate marker } & \multicolumn{2}{c}{$\begin{array}{c}\text { Anti-HIV+ } \\
(\mathrm{n}=39)\end{array}$} & \multicolumn{2}{c}{$\begin{array}{c}\text { Anti-HIV } \\
(\mathrm{n}=80.245)\end{array}$} & \multirow{2}{*}{$\mathrm{p}^{*}$ value } \\
\cline { 2 - 4 } & \multicolumn{1}{c}{$\mathrm{n}$} & \multicolumn{1}{c}{$\%$} & \multicolumn{1}{c}{$\mathrm{n}$} & \multicolumn{1}{c}{$\%$} & \\
\hline Anti-HBc & 12 & 30.80 & 8,407 & 10.50 & $<0.001$ \\
Anti-HCV & 10 & 25.60 & 441 & 0.50 & $<0.001$ \\
Anti-HTLV I/II & 1 & 2.60 & 189 & 0.20 & 0.088 \\
STS & 1 & 2.60 & 464 & 0.60 & 0.203 \\
HBsAg & 1 & 2.60 & 473 & 0.60 & 0.206 \\
\hline
\end{tabular}

p value according to Fisher Exact Test $(\mathrm{p}<0.001)$; Anti-HIV +: human immunodeficiency virus antibody reactive; Anti-HIV - : human immunodeficiency virus antibody nonreactive; Anti-HBc: antibody to hepatitis B virus core antigen; Anti-HCV: hepatitis C virus antibody; Anti-HTLV I/II: human T-lymphotropic virus I and II antibodies; STS: Serologic test for syphilis; HBsAg: hepatitis B virus surface antigen. seropositive donation was $30.80 \%$. A total of 8,407 donations were anti$\mathrm{HBc}$ reactive but not anti-HIV seropositive, corresponding to a PPV of $0.10 \%(95 \% \mathrm{CI}=0.10$ to $0.30 \%)$. The $\mathrm{RP}$ was 3.8 , indicating that the prevalence of anti-HIV positive results among anti-HBc reactive donations was 3.8 times greater than that of anti-HIV-positive results among anti-HBc nonreactive donations. The prevalence of infection with hepatotropic viruses in an anti-HIV-reactive population from Argentina, South America, was investigated and the results showed that the rates of anti-HBc, HBsAg and anti-HCV $(58.50 \%, 14.50 \%$ and $58.50 \%$, respectively) were significantly higher in anti-HIV-positive patients than in the control group $(3.20 \%, 0.50 \%$ and $1.00 \%$, respectively), confirming the high prevalence of $\mathrm{HBV}$ and $\mathrm{HCV}$ infections in HIV-positive patients due to the occurrence of a common epidemiologic factor for the acquisition of these viruses ${ }^{5}$.

Numerous reports have shown the importance of the maintenance of anti-HBc in the routine of blood donor screening to help reduce the risk of post-transfusion $\mathrm{HBV}$ infection and to serve as a surrogate marker for HIV due to the overlapping epidemiology of HBV and HIV infection ${ }^{1,11,12,17}$. During the evaluation of the risk of post-transfusion infectious diseases ${ }^{17}$, it was verified that 6 donations made before antiHIV was detected were not used due the positivity of other serologic surrogate markers such as elevated ALT (one donation), the presence of $\mathrm{HBsAg}$ (one donation), anti-HBc reactivity (two donations), and autoexclusion (two donations). However, the maintenance of this test in routine donor screening has been discussed in numerous studies. One of them ${ }^{13}$, reported that $34.40 \%$ of donations were positive for anti-HBc, but all of them were negative for HIV antigen p24. Moreover, 148 donors had repeat testing for p24 6 to 8 months later and all remained negative. When tested for anti-HBs, $95.70 \%$ were positive, indicating a state of acquired immunity. The other $4.30 \%$ negative for anti-HBs all tested negative for HBV-DNA and probably represented false-positive results, a phenomenon well described with available anti-HBc tests. The results indicated that adding the anti-HBc test to routine donor screening would be unlikely to further reduce the risk of post-transfusion $\mathrm{HBV}$ and/or HIV infection ${ }^{13}$.

The detection of anti-HBc reaction alone could be interpreted in several ways, such as a false-positive result as a consequence of passive transfer of antibodies from blood transfusion, the window period of $\mathrm{HBV}$

Table 3

Sensitivity, positive predictive value, and relative prevalence of serologic surrogate markers for anti-HIV obtained in serum samples from blood donors of the Blood Bank of "Hospital Universitário Regional Norte do Paraná", Londrina, Brazil, from July 1994 to April 2001

\begin{tabular}{|c|c|c|c|c|c|c|}
\hline $\begin{array}{l}\text { Serologic } \\
\text { surrogate } \\
\text { marker }\end{array}$ & $\begin{array}{c}\text { Sensitivity }^{\mathrm{a}} \\
(\%)\end{array}$ & $\begin{array}{c}95 \% \\
\text { Confidence } \\
\text { interval }\end{array}$ & $\begin{array}{l}\text { Positive } \\
\text { predictive } \\
\text { value }^{\mathrm{b}}\end{array}$ & $\begin{array}{c}95 \% \\
\text { Confidence } \\
\text { interval }\end{array}$ & $\begin{array}{c}\text { Relative } \\
\text { prevalence }^{\mathrm{c}}\end{array}$ & $\begin{array}{c}95 \% \\
\text { Confidence } \\
\text { interval }\end{array}$ \\
\hline Anti-HBc + & 30.80 & $17.50-47.70$ & 0.10 & $0.10-0.30$ & 3.80 & $1.90-7.50$ \\
\hline Anti-HCV + & 25.60 & $13.60-42.40$ & 2.21 & $1.10-4.20$ & 60.70 & $29.80-123.80$ \\
\hline Anti-HTLV+ & 2.60 & $0.10-15.10$ & 0.50 & $0.0-3.30$ & 11.10 & $1.50-80.40$ \\
\hline $\mathrm{STS}^{\mathrm{d}}+$ & 2.60 & $0.10-15.10$ & 0.20 & $0.0-1.40$ & 4.50 & $0.60-32.80$ \\
\hline HBsAg+ & 2.60 & $0.10-15.10$ & 0.20 & $0.0-1.40$ & 4.40 & $0.60-32.20$ \\
\hline
\end{tabular}

a: \% of reactive serologic surrogate marker donation among HIV-seropositive donations.; b: \% of HIV-positive donations among reactive serologic surrogate marker donations; c: Positive predictive value divided by \%age of HIV-positive donations among negative serologic surrogate marker donations; d: Serologic test for syphilis + positive 


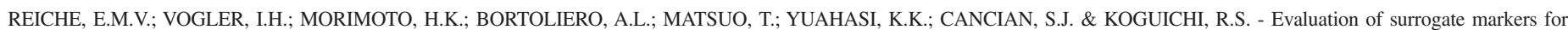
human immunodeficiency virus infection among blood donors at the blood bank of "Hospital Universitário Regional Norte do Paraná", Londrina, PR, Brazil. Rev. Inst. Med. trop. S. Paulo, 45(1):23-27, 2003.

infection, when anti-HBc is the only serologic marker detecting current or past $\mathrm{HBV}$ infection ${ }^{7,8,16}$, and in cases of $\mathrm{HVB}$ variants when it is not possible to detect the presence of $\mathrm{HBsAg}^{14}$.

As regards anti-HCV, among 39 anti-HIV-seropositive donations, $10(25.60 \%)$ were anti-HCV reactive, which means that the sensitivity of anti-HCV in detecting an anti-HIV-seropositive donation was $25.60 \%$ $(95 \% \mathrm{CI}=13.60$ to $42.40 \%)$. There were 441 donations that were anti$\mathrm{HCV}$ reactive but not anti-HIV seropositive, resulting in a PPV of $2.21 \%$ (95\% CI $=1.10$ to $4.20 \%$ ). The RP was 60.70 , indicating that the prevalence of anti-HIV-positive results among anti-HCV-reactive donations was 60.7 times higher than that of anti-HIV-positive results among anti-HCV nonreactive donations.

STS in screening of blood donors has been maintained, in part, to identify and remove from the blood supply donations from persons at risk for HIV infection. Some authors related that the STS could indirectly prevent the residual risk of HIV transmission ${ }^{15}$. However, other studies demonstrated a low PPV of the STS for the HIV infection $(0.06 \%)$, suggesting that this screening prevents the transfusion of few HIV infectious window-period donations ${ }^{6}$. Our results did not show the importance of STS as a surrogate marker for HIV infection. Its sensitivity was $2.60 \%$ (95\% CI $=0.10$ to $15.10 \%$ ), PPV was $0.20 \%$ (95\% CI $=0.0$ to $1.40 \%$ ), and RP 4.5 , which means that the prevalence of anti-HIVpositive results among STS-reactive donations was 4.5 times higher than that of anti-HIV-positive results among STS-nonreactive donations. These results confirmed that the STS screening is a poor marker and a costly strategy for preventing post-screening HIV infections and other bloodborne diseases, preventing the transfusion of few HIV infections windowperiod donations ${ }^{2}$.

Although the present results for anti-HTLVI/II were not statistically significant for its use as a surrogate marker for HIV infection, the RP obtained of $11.10(95 \% \mathrm{CI}=1.50$ to $80.40 \%)$ indicated that the prevalence of anti-HIV-positive results among anti-HTLV I/II-reactive donations was 11.1 times greater than that of anti-HIV-positive results among antiHTLV I/II nonreactive donations.

HTLV I/II share the same modes of transmission and risk factors as HIV. Thus, an overlap in exposure to these retroviruses is expected. The evaluation of the seroprevalence of HTLV I/II infections and their risk factors in HIV-seropositive individuals in Santos, São Paulo (Brazil) revealed an independent association of HTLV I/II infection with intravenous drug use and $\mathrm{HCV}$ seropositivity and the results indicated that HIV-infected individuals are at high and similar risk to be exposed to HTLV I/II infections ${ }^{4}$.

The low PPV obtained for all the surrogate markers for HIV infection evaluated is explained in part by the low rates of seroprevalence of this retroviral infection $(0.05 \%)$ among the blood donors included in this study. Other factors could be the sensitivity and the specificity of the methods assayed to detected the surrogate markers. Lack of specificity in the detection of these surrogate markers for anti-HIV creates significant numbers of false-positive results and contributes to the low VPP, resulting in problems for the donor and blood banking community, such as unit loss, donor loss, unnecessary apprehension, and medical follow-up for the donors. Although the predictive positive value for these surrogate markers were low for HIV infection, the results confirmed the anti-HBc and anti-HCV as useful surrogate markers for HIV infection and reinforcing the maintenance of them in the screening for blood donors contributing, in part, to the prevention of the small number of cases in which HIV that is still transmitted by transfusion. The results also reinforce the importance of the clinical and laboratory follow-up of the blood donors with reactivity of these surrogate markers, even without symptoms, in order to detect other infectious agents. As regard to HIV infection, efforts should be focused on other strategies to reduce the risk of post-transfusion of this retroviral infection. The introduction of HIV p24 antigen tests and the nucleic acid amplification techniques such as the polymerase chain reaction, are suitable methods to close the diagnostic window in blood donation screening. The introduction of these new tests in the routine serological screening also in developing countries, should be possible to increase the sensitivity of HIV diagnosis so that fewer donations will be overlooked in the diagnostic window phase and, in this way, the effectiveness of blood donor screening and the safety of the blood components will be significantly improved.

\section{RESUMO}

\section{Avaliação dos marcadores indiretos na infecção pelo vírus da imunodeficiência humana (HIV) entre doadores de sangue do hemocentro do "Hospital Universitário Regional Norte do Paraná", Londrina, PR, Brasil}

Este estudo avaliou a utilidade dos testes sorológicos para pesquisa de anticorpos anti-antígeno "core" do vírus da hepatite B (anti-HBc), anti-vírus da hepatite $\mathrm{C}$ (anti-HCV), anti-vírus linfotrópico de células $\mathrm{T}$ humanas tipos I e II (anti-HTLV I/II), testes sorológicos para sífilis e pesquisa do antígeno de superfície do vírus da hepatite B (HBsAg) como marcadores sorológicos indiretos do risco de infecção pelo vírus da imunodeficiência humana (HIV) em 80.284 amostras de soro de doadores de sangue do Hemocentro do Hospital Universitário Regional Norte do Paraná, Londrina, do período de julho de 1994 a abril de 2001. Entre 39 doadores de sangue com sorologia positiva para HIV, $12(30,8 \%)$ apresentaram anti-HBc, $10(25,6 \%)$ anti-HCV, 1 (2,6\%) anti-HTLV I/II, $1(2,6 \%)$ sorologia reagente para sífilis, e $1(2,6 \%)$ a presença de HBsAg. Entre os doadores com sorologia negativa para HIV, estes marcadores foram detectados em 8.407 (10,5\%), $441(0,5 \%), 189(0,2 \%), 464(0,6 \%)$, e $473(0,6 \%)$ amostras, respectivamente. A diferença foi estatisticamente significativa $(\mathrm{p}<0,001)$ para anti-HBc e anti-HCV. Embora o valor preditivo positivo para estes marcadores para a infecção pelo HIV foi baixo, os resultados confirmam a importância do anti-HBc e o anti-HCV como marcadores indiretos úteis da infecção por HIV em doadores de sangue e reforçam a sua manutenção na triagem sorológica dos doadores de sangue contribuindo para a prevenção do pequeno número de casos em que o HIV é ainda transmitido por transfusão.

\section{REFERENCES}

1. BASSIT, L.; SAEZ-ALQUEZAR, A.; ROMANO, C.C. et al. - Estudo comparativo entre anti-HIV e anti-HBc em doadores de sangue na Fundação Pró-Sangue Hemocentro de São Paulo. Bol. Soc. bras. Hemat. Hemot., 16(165): 133, 1994.

2. CASE, J. - Serologic test for syphilis: a discredited surrogate test for HIV infection. Letter. Transfusion, 38: 218, 1998.

3. CHOO, Q.L.; KUO, G.; WEINER, A.J. et al. - Isolation of a cDNA clone derived from a blood-borne non-A, non-B viral hepatitis genome. Science, 244: 359-362, 1989. 


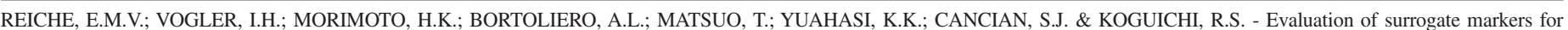

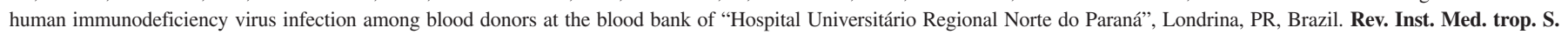
Paulo, 45(1):23-27, 2003.

4. ETZEL, A. - Infecção pelos vírus linfotrópicos de células $\mathbf{T}$ humanas dos tipos $\mathbf{I}$ (HTLV I) e II (HTLV II) em portadores do HIV em Santos-SP: estudo de prevalência e fatores de risco. São Paulo, 1999. (Dissertação de Mestrado - Faculdade de Medicina da Universidade de São Paulo).

5. FAINBOIM, H.; GONZALEZ, J.; FASSIO, E. et al. - Prevalence of hepatitis viruses in an anti-human immunodeficiency virus-positive population from Argentina. A multicentre study. J. viral Hepatitis, 6: 53-57, 1999.

6. HERRERA, G.A.; LACKRITZ, E.N.; JANSSEN, R.S. et al. - Serologic test for syphilis as a surrogate marker for human immunodeficiency virus infection among United States blood donors. Transfusion, 37: 836-840, 1997.

7. INOUYE, M.M.Z.; REICHE, E.M.V. \& PONTELLO, R. - Marcadores sorológicos da hepatite por vírus B (HBV): a detecção de anti-HBcAg em indivíduos $\mathrm{HBsAg}$ negativos como sinal de alerta na hepatite por vírus B pós-transfusional. Semina (Londrina), 13: 102-104, 1992.

8. KATCHAKI, J.N.; BROUWER, R. \& SIEM, T.H. - Anti-HBc and blood infectivity. New Engl. J. Med., 298: 1421-1422, 1978.

9. KORELITZ, J.J.; BUSCH, M.P.; KLEINMAN, S.H. et al. - Relationship between antibody to hepatitis B core antigen and retroviral infections in blood from volunteer donors. Transfusion, 36: 232-237, 1996.

10. LACKRITZ, E.M. - Prevention of HIV transmission by blood transfusion in the developing world: achievements and continuing challenges. AIDS, 12 (suppl. A): S81-S86, 1998.

11. LACKRITZ, E.M.; SATTEN, G.A.; ABERLE-GRASSE, J. et al. - Estimated risk of transmission of the human immunodeficiency virus by screened blood in the United States. New Engl. J. Med., 333: 1721-1725, 1995.

12. LEITMAN, S.F.; KLEIN, H.G.; MELPOLDER, J.J. et al. - Clinical implications of positive tests for antibodies to human immunodeficiency virus type 1 in asymptomatic blood donors. New Engl. J. Med., 321: 917-924, 1989.
13. MAHMOUD, M.Y.; EL-TAHAWY, M.A.; ZAKI, A.M. et al. - Value of anti-HBc in donor screening. Brit. J. Haemat., 105 (suppl.1): 50, 1999.

14. SÁEZ-ALQUÉZAR, A.; BASSIT, L. \& SABINO, E.C. - Hepatites virais. In: FERREIRA, A.W. \& ÁVILA, S.M., ed. Diagnóstico laboratorial das principais doenças infecciosas e auto-imunes. 2. ed. Rio de Janeiro, Guanabara Koogan, 2001. p. 74 91.

15. SÁEZ-ALQUÉZAR, A.; SALES, N.A. \& CHAMONE, D.A.F. - Triagem sorológica em bancos de sangue. In: VERONESI, R. \& FOCACCIA, R., ed. Tratado de Infectologia. São Paulo, Atheneu, 1997. p. 1743-1751.

16. SARNO, E.N.; ALVARIZ, F.G.; SILVA, D.B.; RUZANY, F. \& PEREIRA, J.L. - "Anticore" como indicação de infecção pelo vírus B da hepatite. Rev. Inst. Med. trop. S. Paulo, 19: 374-377,1977.

17. SCHREIBER, G.B.; BUSCH, M.P.; KLEINMAN, S.H. \& KORELITZ, J.J. - The risk of transfusion-transmitted viral infections. The Retrovirus Epidemiology Donor Study. New Engl. J. Med., 334: 1685-1690, 1996.

18. SEGURADO, A.A.C. - Infecção por HTLV I e HTLV II. In: FERREIRA, A.W. \& ÁVILA S.M. Diagnóstico laboratorial das principais doenças infecciosas e auto-imunes. 2. ed. Rio de Janeiro, Guanabara Koogan, 2001. p. 103-110.

19. WALLACH, J. - Interpretação de exames de laboratório. 6. ed. Rio de Janeiro, Ed. Médica e Científica, 1999. p. 220-230.

20. WEARE, J.A.; ROBERTSON, E.F.; MADSEN, G.; HU, R. \& DECKER, R.H. Improvement in the specificity of assays for detection of antibody to hepatitis B core antigen. J. clin. Microbiol., 29: 600-604, 1991.

Received: 10 May 2002

Accepted: 03 October 2002 